\title{
Habitat Associations of Vertebrate Prey within the Controlled Area Study Zone
}
N. V. Marr
R. E. Fitzner
C. A. Brandt
L. D. Poole

March 1988

Prepared for the U.S. Department of Energy under Contract DE-AC06-76RLO 1830

Pacific Northwest Laboratory

Operated for the U.S. Department of Energy

by Battelle Memorial Institute 


\section{DISCLAIMER}

This report was prepared as an account of work sponsored by an agency of the United States Government. Neither the United States Government nor any agency thereof, nor Battelle Memorial Institute, nor any or their employees, makes any warranty, expressed or implied, or assumes any legal liability or responsibility for the accuracy, completeness, or usefulness of any information, apparatus, product, or process disclosed, or represents that its use would not infringe privately owned rights. Reference herein to any specific commercial product, process, or service by trade name, trademark, manufacturer, or otherwise does not necessarily constitute or imply its endorsement, recommendation, or favoring by the United States Government or any agency thereof, or Battelle Memorial Institute. The views and opinions of authors expressed herein do not necessarily state or reflect those of the United States Government or any agency thereof, or Battelle Memorial Institute.

\section{PACIFIC NORTHWEST LABORATORY operated by \\ BATTELLE MEMORIAL INSTITUTE for the UNITED STATES DEPARTMENT OF ENERGY under Contract DE-AC06-76RLO 1830}

\begin{tabular}{|c|c|}
\hline \multicolumn{2}{|c|}{$\begin{array}{c}\text { Printed in the United States of America } \\
\text { Available from } \\
\text { National Technical Information Service } \\
\text { United States Department of Commerce } \\
5285 \text { Port Royal Road } \\
\text { Springfield, Virginia } 22161\end{array}$} \\
\hline \multicolumn{2}{|c|}{$\begin{array}{l}\text { NTIS Price Codes } \\
\text { Microfiche } \mathrm{A} 01\end{array}$} \\
\hline \multicolumn{2}{|c|}{ Printed Copy } \\
\hline Pages & $\begin{array}{l}\text { Price } \\
\text { Codes }\end{array}$ \\
\hline $001-025$ & $\mathrm{~A} 02$ \\
\hline $026-050$ & $\mathrm{~A} 03$ \\
\hline $051-075$ & $\mathrm{~A} 04$ \\
\hline $076-100$ & A05 \\
\hline $107-125$ & 406 \\
\hline $126-150$ & $\mathrm{~A} 07$ \\
\hline $151-175$ & $\mathrm{~A} 08$ \\
\hline $176-200$ & A09 \\
\hline $201-225$ & $\mathrm{~A} 010$ \\
\hline $226-250$ & A011 \\
\hline $251-275$ & $\mathrm{~A} 012$ \\
\hline $276-300$ & A013 \\
\hline
\end{tabular}



N. V. Mart
C. A. Brandt
R. E. Fizner
L. D. Poole

March 1988

Prepared for
the U.S. Department of Energy
under Contract DE-AC06-76RLO 1830

Pacific Northwest Laboratory

Richland, Washington 99352 



\section{PREFACE}

In 1986, the U.S. Department of Energy (DOE) selected the Hanford Site, Washington, for further study as a permanent repository for commercial spent nuclear fuel and high-level radioactive waste. The DOE then initiated a site characterization program to obtain the information necessary for evaluating the suitability of locating a repository at the Hanford Site. These characterization activities were part of the Basalt Waste Isolation Project (BWIP). Pacific Northwest Laboratory (PNL) was contracted by the DOE to do the ervironmental studies. The DOE was required by Section 113(A) of the Nuclear Waste Policy Act (NWPA) to "conduct site characterization activities in a manner that minimizes any significant adverse ervironmental impacts identified ..."

This document is part of the Environmental Topical Report series. Each report presents the results of the environmental monitoring studies at the BWIP site, up until BWIP was closed in response to the enactment of the Nuclear Waste Amendments Act of 1987. Some of the reports are preliminary because not all task objectives were completed at project close-out. However, they can serve as a reference source for other BWIP environmental reports related to site closure and reclamation. These Environmental Topical Reports are listed below:

1. Cold-Blooded Vertebrates at the Proposed Reference Repository Location in Southeastern Washington, by R. E. Fitzner, January 1988, PNL-6440.

2. Natural Vegetation at the Proposed Reference Repository Location in Southeastem Washington, by W. H. Rickard, February 1988, PNL-6402.

3. Bird Associations With Shrubsteppe Plant Communities at the Proposed Reference Repository Location in Southeastern Washington, by C. A. Schuler, W. H. Rickard, and G. A. Sargeant, March 1988, PNL-6493.

4. Descriptions of Plant Communities at the Proposed Reference Repository Location and Implications for Reclamation of Disturbed Ground, by W. H. Rickard and C. A. Schuler, March 1988, PNL-6494.

5. Habitat Associations of Ventebrate Prey Within the Controlled Area Study Zone, by N. V. Marr, C. A. Brandt, R. E. Fitzner, and L. D. Poole, March 1988, PNL-6495.

6. Productivity, Mortality, and Response to Disturbance of Nesting Swainson's Hawks on the Hanford Site, by L. D. Poole, N. V. Marr, R. E. Fitzner, and S. M. McCorquodale, March 1988, PNL-6496.

7. Water Quality: Historic Values and Impact of Drilling Activities During FY1988 at the Reference Repository Location in Southeastern Washington, by P. A. Eddy, S. S. Teel, J. R. Raymond, and W. H. Biershank, March 1988,. PNL-6497. 


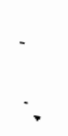

$\cdots$ 


\section{SUMMARY}

The information in this report is intended for use in designing future plans for assessing environmental impacts and monitoring change in the Hanford vertebrate biota. The data reported were to be used in this capacity as part of the environmental monitoring program for the Basalt Waste Isolation Project.

Twelve study locations were established in nine habitat types in the vicinity of the proposed reference repository location. Eight species of small mammals were captured. Great Basin pocket mice (Perognathus parvus) comprised the majority of individuals captured, followed by deer mice (Peromyscus maniculatus). Other small mammals captured included the Northern pocket gopher (Thomomys talpoides) Western harvest mouse (Reithrodontomys megalotus), Grasshopper mouse (Onychomys leucogaster), Montane vole (Microtus montanus), House mouse (Mus musculus), and the Bushy-tailed woodrat (Neotoma cinerea). Pocket mice were captured in all habitats sampled; deer mice were obtained in all habitats save hopsage and nearly pure cheatgrass stands. The highest capture rates were found in bitterbrush and riparian habitats. Capture sex ratios for both pocket mice and deer mice were significantly different from equality. Body weights for deer mice and pocket mice exhibited a great deal of heterogeneity across trap sites, although only the heterogeneity for pocket mice was significant. In general, body weights for both species were greater in the sagebrush habitats than elsewhere. These differences are interpreted in light of habitat evaluation methodologies.

Six species of reptiles and one species of amphibian were captured. Side-blotched lizards (Uta stansburiana) were by far the most frequently captured species. Snakes comprised $25 \%$ of all herpetiles captured. The predominant snakes captured were the yellow-bellied racer (Coluber constrictor) and the Great Basin gopher snake (Pituophis melanoleucus). Only two amphibians were captured. Both were Great Basin spadefoot toads (Scaphiopus intermontanus)_captured at the Rattlesnake Springs trap site. Species diversity was quite low (Shannon-Wiener $H=1.03$ ). Side-blotched lizards were found in all habitats save near the talus on Gable Mountain and on the gravel pad site. Wherever present, side-blotched lizards were the most common herpetile. The only other lizard species [northern sagebrush lizard (Sceloporus graciosus) and short-horned lizard (Phrynosoma douglasii) ] were obtained in bitterbrush habitat. 



\section{CONTENTS}

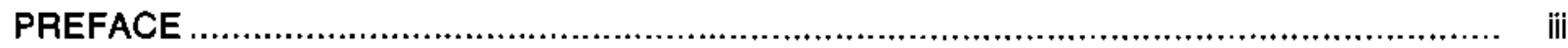

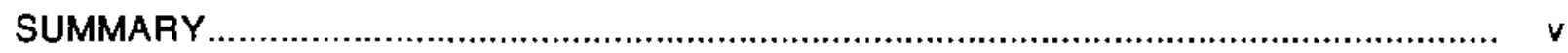

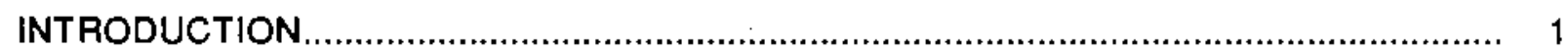

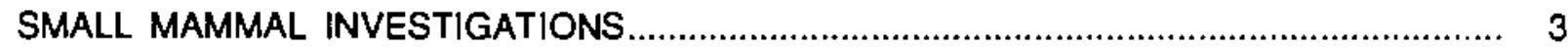

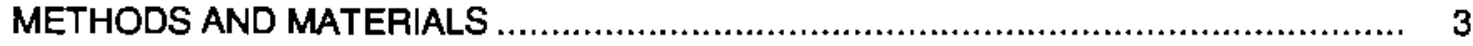

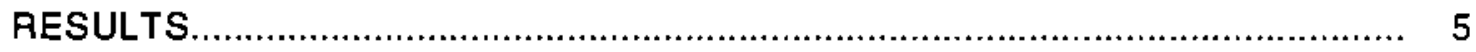

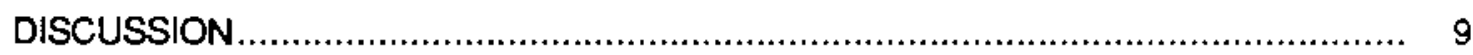

COLD-BLOODED VERTEBRATE INVESTIGATIONS ................................................... 13

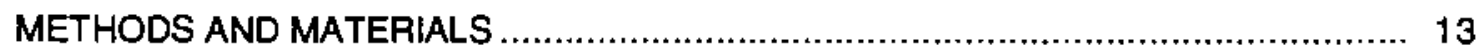

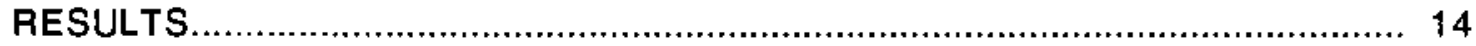

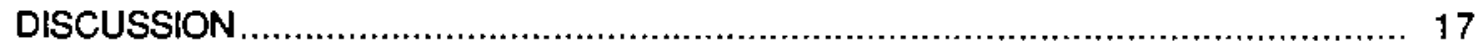

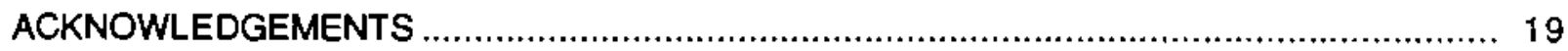

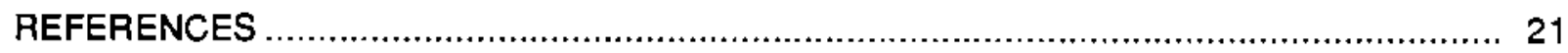




\section{EIGURES}

1 Locations of Trapping Sites......

\section{TABLES}

1 Trapping Effort and Capture Rates of Small Marnmals AcrossTrapping Sites

2 Common and Scientific Names of Small Mammals Trapped in the Present Study

3 Number of Individual Small Mammals Captured in Each Habitat Sampled.

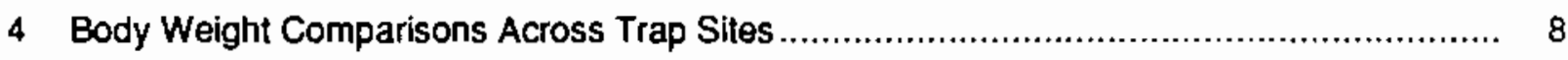

5 Relationship Between Sex and Age Versus Weight for Pocket Mice and Deer Mice Captures.

6 Trapping Effort and Capture Rates of Cold-Blooded Vertebrates Across Trapping Sites.

7 Common and Scientific Names of Herpetiles Trapped in the Present Study

8 Number of Individual Herpetiles Captured in Each Habitat Sampled............................... 16

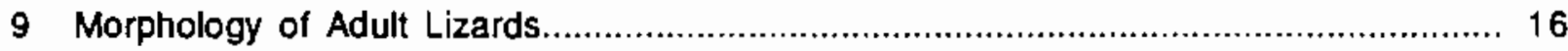




\section{INTRODUCTION}

In 1986, the U.S. Department of Energy (DOE) recommended the Hanford Site in southeastern Washington for further study as a potential location for the nation's first repository for commercial high-level nuclear waste. The DOE subsequently prepared a series of plans with the intent of further characterizing and evaluating the Hanford Site in support of the site selection process. As part of this overall site characterization effort, the Pacific Northwest Laboratory was charged with monitoring potentially significant impacts to terrestrial and aquatic ecosystems caused by site characterization activities.

Impact assessment studies commonly focus primarily on species protected by local, state, or federal regulations and statutes. Such studies typically focus on habitat requirements (USFWS 1980a). However, the Nuclear Regulatory Commission (NRC 1976) requires knowledge of key prey availability and distributions in assessing the potential impact of nuclear siting and construction activities. On the Hanford Site, protected species consist almost exclusively of raptors. Unlike many species, which may move their foraging areas in response to disturbance, nesting raptors are centrai-place foragers. This foraging pattern limits the bird's ability to realocate foraging efforts to new areas as a response to changes in their prey base. While no protected prey species occur on the Hanford Site, a number of key prey are present.

The present studies were initiated in order to provide baseline information on population parameters and habitat affinities for small mammals and herpetofauna that serve as the principal prey items for Hanford raptors. These studies were to serve as the basis for more quantitative impact-detection programs that were to be initiated in 1988. However, the Nuclear Waste Policy Amendments Act of 1987 terminated all site characterization activities at Hanford as of March 22, 1988. It is hoped that the present report will be a useful aid to reclamation of activity sites on the Hanford Site, and may serve as a basis for other impact-detection studies. 



\section{SMALL MAMMAL INVESTIGATIONS}

The primary objective of this task was to assess species composition and relative abundance of small mammals in habitats similar to those likely to be affected by activities associated with the Basalt Waste Isolation Project. An additional objective was to provide estimates of natural variability (in time and space) in population parameters relevant to quantitative detection of projectinduced change.

\section{METHODS AND MATERIALS}

We established five trapping sites in three habitat types during July 1986 (Figure 1). Three sites were in big sagebrush (Artemisia tridentata) habitat (sites 1,3,4), one in spiny hopsage (Grayia spinosa) habitat (2), and one in burned sagebrush habitat that is now dominated by cheatgrass (Bromus tectorum) and Russian thistle (Salsola kall) (5). Non-collapsible Sherman live traps were arranged in a 5 by 12 grid with $10-\mathrm{m}$ spacing between trapping stations. Two traps were set at each perimeter station and single traps were set at all interior stations. Pitfall traps ( 5 by 5 grid with $10-\mathrm{m}$ spacing) were located adjacent to the live trapping grids. One-gallon cans were buried flush with the ground surface and provided with wooden covers.

In May 1987, the emphasis shifted from estimating natural variability in population parameters to getting better information on the diversity of small mammal species, particularly those of concern to the State of Washington. To that end, the 5 by 12 grids were changed to 5 by 5 grids with two live traps at each station. Also two collapsible Sherman live traps were set within 1-m of each of the pitfall traps. Seven additional trapping sites were established between May and June of 1987 in seven habitat types (Figure 1). One site each was placed in big sagebrush (S), bitterbrush (Purshia tridentata) (B), and rabbitbrush (Chrysothamnus spp.) (R) dominated habitats. One site was placed in a sagebrush-hopsage habitat associated with nearby talus (G); another was set in an area of compacted gravel with sparse vegetation (C). The sixth site was located in a burnrecovery area along a Russian thistle "drift" against a fence (T); the final site was located in a narrow riparian area along Rattlesnake Springs (RS). Trapping stations were arranged in single, double or triple rows with traps and rows spaced at least 10-m apart. Each trapping station included a onegallon buried pitfall trap with wooden cover and two collapsible Sherman live traps.

From July 1986 to January 1987, live traps were baited with peanut-butter-flavored bird seed. Beginning in May 1987, a mixture of rolled oats, peanut butter, bacon grease, raisins, and sliced carrot was used as bait. During the winter trapping session, cotton batting was placed 


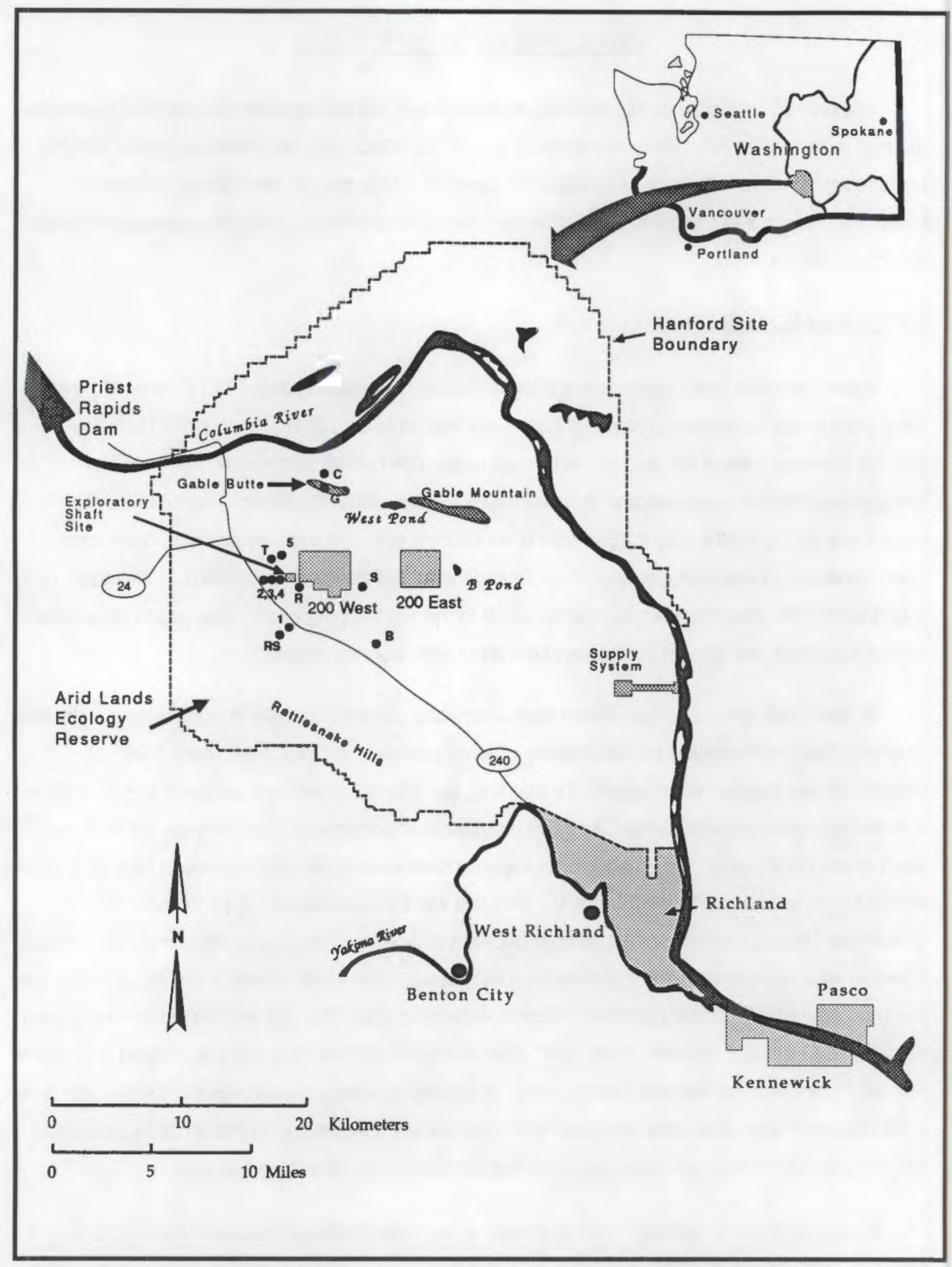

FIGURE 1. Locations of Trapping Sites (habitat designations defined in text) 
inside each trap as insulation, and extra bait was supplied to allow trapped animals to survive until traps were checked and reset the following day. During summer trapping sessions, traps were set so as to be in shade during the morning hours. Trigger sensitivity was checked and adjusted when necessary as each trap was set.

Traps were set on the first afternoon of each trapping session and checked each morning for the following five mornings (from July 1986 through January 1987) or the following four mornings (from May through August 1987). All traps were closed during midday and reset late in the afternoon. On the last morning of each trapping session, all pitfall traps were covered to prevent entry by animals, and all live traps were closed or removed.

Trapped animals were transferred to plastic bags for handling. Animals were marked with an individual combination of toe amputations and ear notches and weighed using Pesola spring scales. Ages were estimated on the basis of pelage (Peromyscus maniculatus) or size (Perognathus parvus). Sex was determined by the presence or absence of an evertible penis. The trap coordinates, species, sex, identification number, reproductive condition, presumed age, and weight of trapped animals were recorded onto field forms, which were later placed into laboratory record books for storage. Statistics were calculated using Statyiew $512 \pm$ for the Macintosh@ (BrainPower 1986).

\section{RESULTS}

We trapped for a total of 30,441 trap-nights distributed unequally over the 12 trapping sites (Table 1) and made 1446 captures (542 individuals). Because the focus of this study was not to derive estimates of species density across habitat types, but merely to determine habitat affinities for common species, we will confine our analysis of habitat relationships to qualitative descriptions of associations. Eight species of small mammals were captured (Table 2). Great Basin pocket mice comprised the majority of individuals captured ( $81 \%$ ), followed by deer mice (15\%) (Table 3). Pocket mice were captured in all habitats sampled; deer mice were obtained in all habitats save hopsage and nearly pure cheatgrass stands. Few other species were encountered, indicating either their relative scarcity or the selectivity of the trapping method (e.g., for pocket gophers). 
IABLE1. Trapping Effort and Capture Rates of Small Mammals Across Trapping Sites

\begin{tabular}{|c|c|c|c|c|}
\hline \multirow[b]{2}{*}{ Habitat } & \multirow[b]{2}{*}{ Site } & \multicolumn{2}{|c|}{ Trap - Niahts } & \multirow{2}{*}{$\begin{array}{c}\text { Capture Rate } \\
\text { per. } 100 \text { trap Nights }\end{array}$} \\
\hline & & Pitfall traps & Live traps & \\
\hline Sagebrush & $\begin{array}{r}1 \\
3 \\
4 \\
\mathrm{~S}\end{array}$ & $\begin{array}{r}1325 \\
1325 \\
1325 \\
400 \\
4375\end{array}$ & $\begin{array}{r}2540 \\
2540 \\
2698 \\
800 \\
8578\end{array}$ & $\begin{array}{l}3.93 \\
1.61 \\
1.63 \\
3.00 \\
2.44\end{array}$ \\
\hline Hopsage & 2 & 1350 & 2540 & 1.77 \\
\hline $\begin{array}{l}\text { Cheatgrass, Russial } \\
\text { thistle }\end{array}$ & 5 & 1300 & 2698 & 1.63 \\
\hline Bitterbrush & B & 600 & 1200 & 7.50 \\
\hline Rabbitbrush & $\mathrm{R}$ & 600 & 1200 & 1.92 \\
\hline Russian thistle & $T$ & 600 & 1200 & 0.92 \\
\hline Riparian & RS & 600 & 1200 & 5.92 \\
\hline Mixed shrub, talus & G & 400 & 800 & 3.75 \\
\hline $\begin{array}{l}\text { Cheatgrass, prickly } \\
\text { leftuce, gravel pad }\end{array}$ & C & 400 & 800 & 3.75 \\
\hline
\end{tabular}

IABLE 2. Common and Scientific Names of Small Mammals Trapped in the Present Study

\section{Common name}

Northem pocket gopher

Great Basin pocket mouse

Western harvest mouse

Deer mouse

Grasshopper mouse

Montane vole

House mouse

Bushy-tailed woodrat
Scientific name

Thomomys talpoides

Perognathus parvus

Reithrodontomys megalotus

Peromyscus maniculatus

Onychomys laucogaster

Microtus montanus

Mus musculus

Neotoma cinerea 
IABLE3. Number of Individual Small Mammals Captured in each Habitat Sampled

\section{Habitat}

Sagebrush

Riparian

Bitterbrush

Hopsage

Rabbitbrush

Mixed shrub

Cheatgrass, Russian

thistle

Russian thistle

Cheatgrass, prickly

lettuce aravel pad

TOTAL

\section{Pecket mouse}

159

53

70

32

22

18

43

10

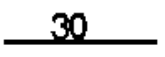

437

\section{Deer mouse}

47

13

20

0

1

10

0

1

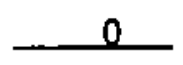

92

\section{Other (species)}

2 (montane vole), 1 (pocket gopher)

1 (house mouse), 1 (pocket gopher)

0

4 (harvest mouse)

1 (grasshopper mouse)

2 (woodrat)

1 (harvest mouse)

0

0

13

Capture rates per trap night were quite variable (Table 1). Much of this variation can be attributed to differences in trapping designs and schedules, however analyses among similar designs and schedules do provide some information on the relative efficiencies across habitat types. Within-habitat variation can be estimated for sites 1,3 , and 4 (sagebrush stands). The average capture rate per 100 trap nights for these areas was 2.39 , with a variance of 1.78 . In contrast, capture rates across habitat types were much more variable. The average capture rate per 100 trap nights for sites $B, R, T$, and RS was 4.07 , with a variance of 9.91 . The highest capture rates were found in bitterbrush and riparian habitats, however these rates cannot be considered good indicators of relative density because of the inter-site variability in trap layout, trapping periods, and trapping durations.

Capture sex ratios for both pocket mice and deer mice were significantly different from equality. Of 1236 captures of pocket mice, $697(56 \%)$ were males $\left(\chi^{2}=20.2, \mathrm{df}=2, P<0.0001\right)$. Similarly, of 166 captures of deer mice, $120(72 \%)$ were males $\left(\chi^{2}=32.99, \mathrm{df}=2, P<0.0001\right)$. These relationships held when individuals rather than captures were analyzed. Of 344 individual pocket mice captured, $192(56 \%)$ were males $\left(\chi^{2}=4.65\right.$, df $\left.=2, P=0.031\right)$; of 53 deer mice captured, $38(72 \%)$ were males $\left(\chi^{2}=9.98, \mathrm{df}=2, P=0.002\right)$. Pocket mouse sex ratios differed significantly from equality only on sites 2 through 5 , while deer mouse sex ratios differed significantly only on sites 1 through 3 and $G$. 
Body weights for deer mice and pocket mice exhibited a great deal of heterogeneity across trap sites, although only the heterogeneity for pocket mice was significant (Table 4). In general, body weights for both species were greater in the sagebrush habitats than elsewhere .

Sex ratios and age ratios of captured mice exhibited significant heterogeneity between trap sites (Pocketmice: age: $\chi^{2}=32.75, \mathrm{df}=11, P=0.0006$; sex: $\chi^{2}=59.89$, df $=11, P<0.0001$; Deer mice: age: $\chi^{2}=17.449, \mathrm{df}=7, P=0.0258$ ). For both species, age and sex were significantly related to body size (Table 5): males were larger than females and adults were larger than subadults for both species. In the case of deer mice, weight and age are of necessity correlated since weight was used to classify animals into age classes.

\section{IABLE 4. Body Weight Comparisons Across Trap Sites}

$$
\text { Pocketmice - Overall F 11, } 1098=10.843, P<0.0001
$$

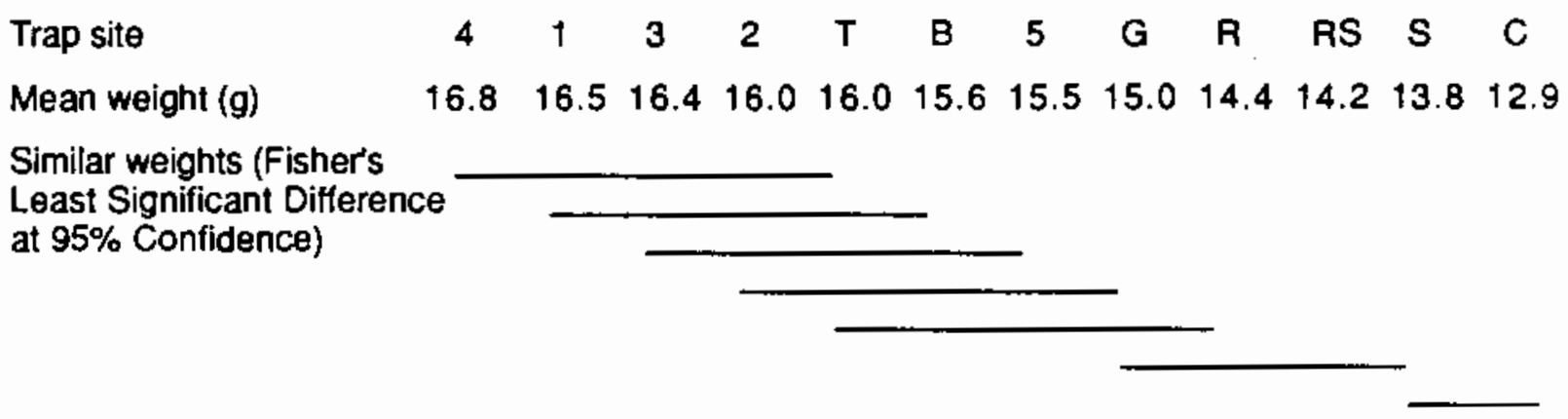

Deer mice - Overall F 8, $126=1.724, P<0.1$

$\begin{array}{lccccccccc}\text { Trap site } & 1 & \text { R } & \text { G } & 4 & 3 & \text { B } & 2 & \text { RS } & \text { T } \\ \text { Mean weight }(g) & 16.4 & 16.0 & 16.0 & 15.6 & 15.5 & 15.1 & 14.8 & 12.8 & 11.5\end{array}$

Similar weights (Fisher's Least Significant Difference at $95 \%$ Confidence) 
IABLE_5. Relationship Between Sex and Age Versus Weight for Pocket Mice and Deer Mice Captures

Source df Sum of Squares Meansquare $E \quad E$

Deer mice:

$\begin{array}{lrrrrr}\text { Sex } & 1 & 39.844 & 39.844 & 5.186 & 0.0235 \\ \text { Age } & 1 & 1490.224 & 1490.224 & 193.962 & 0.0001 \\ \text { Sex X Age } & 1 & 2.473 & 2.473 & 0.322 & 0.5709 \\ \text { Error } & 304 & 2335.651 & 7.683 & & \\ \text { cket mice: } & & & & & \\ \text { Sex } & 1 & 123.214 & 123.214 & 15.738 & 0.0001 \\ \text { Age } & 1 & 4864.88 & 4864.88 & 621.374 & 0.0001 \\ \text { Sex } & 1 & 10.109 & 10.109 & 1.291 & 0.2561 \\ \text { Error } & 958 & 7500.399 & 7.829 & & \end{array}$

\section{DISCUSSION}

The habitat associations and relative species numbers within habitats observed in the present study parallel those documented in other studies of the Hanford Site. O'Farrell's (1975) extensive studies of the Hanford Site showed the predominant small mammal to be the Great Basin pocket mouse, which was obtained in all habitats sampled. Deer mice apparently also occur throughout the 200 Area plateau (Hedlund and Rogers 1976), though at much lower densities than pocket mice, except at the highest elevations on Rattlesnake Mountain (O'Farrell 1975). Gano and Rickard (1982) reported that pure stands of cheatgrass supported lower densities of deer mice than did mixed sagebrush stands.

Gano and Rickard (1982) obtained low numbers of grasshopper mice in a rabbitbrush/cheatgrass community in the southeast section of the Hanford Site. Densities in this area were a factor of 20 to 30 less than that of the Great Basin pocket mouse. O'Farrell (1975) suggested that the distribution of this insectivorous animal is tied to the distribution of grounddwelling beetles. The present study and others indicate that the western harvest mouse is another scarce inhabitant of the Hanford Site. O'Farrell and coworkers (1975) thought harvest mice typical only of riparian vegetation around local springs. Harvest mice have been occasionally caught in xeric areas on the 200-Area plateau (Hedlund and Rogers 1976), though such animals were thought to represent dispersers (O'Farreil et al. 1975). In contrast, later 
studies conducted at $533 \mathrm{~m}$ elevation on the ALE reserve (Gano et al. 1983) found harvest mice to be the third most abundant smail mammal in the sagebrush/bluebrush wheatgrass (Agropyron spicatum) habitats, following the Great Basin pocket mouse and the deer mouse, and the second most abundant small mammal in Old Fields.

O'Farrell and coworkers captured only three montane voles in 7 years of trapping on the ALE reserve (O'Farrell et al. 1975). The present study nearly doubles those numbers. O'Farrell and coworkers presumed their captures to represent animals in the process of dispersing between distant habitat sites. The distribution of montane voles was thought to be limited to dense, herbaceous vegetation associated with riparian areas (Rickard, Hedlund, and Schreckhise 1974). Northern pocket gophers have been found throughout the Hanford Site, with the greatest densities occurring in the abandoned agricultural fields in the Rattlesnake Mountain area (Rickard, Hedlund, and Schreckhise 1974). The bushy-tailed woodrat is sparsely distributed on the Hanford Site, and is primarily associated with rocky areas on Rattlesnake Mountain and Gable Mountain and with abandoned human habitations (O'Farrell 1975; Rickard, Hedlund, and Schreckhise 1974).

House mice generally are found in association with human habitations and construction and seldom on the shrubsteppe itself (Rickard, Hedlund, and Schreckhise 1974). Occasional captures have been made near the U Pond (Gano 1979), suggesting a relationship with riparian areas. However, the present study represents the first report of house mice from the vicinity of Rattlesnake Springs.

The sagebrush vole (Lagurus curtatus), a Washington State Monitor species, was not obtained in any of the areas surveyed. Sagebrush voles are known to occur on the Hanford Site, though their distribution may be limited to higher elevations and relatively more mesic conditions than for the other small mammals (Rickard, Hedlund, and Schreckhise 1974). Another small mammal of interest, Merriam's shrew (Sorex merriami). Washington State proposed sensitive species, has been reported on the Hanford Site (Rickard, Hedlund, Schreckhise 1974). Merriam's shrews have turned up in the diets of long-eared owls and burrowing owls nesting on the Hanford Site (Fitzner et al. 1980). Monitoring the status of these species through the use of trapping would likely be prohibitive. Alternative approaches to impact assessment, such as censuses of raptor pellets and castings or radiotracking captured animals are likely to provide more and better data.

The deviation from equal sex ratios for deer mice and pocket mice reported in the present study may be real, may be due to sexual differences in home range size or trap shyness, or may 
reflect an interaction between sampling dates and the sex-specific phenology of breeding and torpor in these species. For example, pocket mice emerge from winter torpor in February and March, with yearling males appearing first. Adult males appear next in March, with females emerging in April; juveniles and subadults begin appearing from June through September. Adult males return to torpor before adult females (O'Farrell et al. 1975).

Similarly, the differences observed in body weight across habitat types can be attributed to any of several causes. First, both sex ratios and age ratios of captured mice exhibited significant heterogeneity between trap sites. A second cause for some of the body weight-by-habitat differences may be nonrandom experimental error. Age categorizations for both species were based on subjective criteria, and errors of classification are expected as a result. However, the magnitudes and distributions of these errors cannot be estimated, and are likely not to be randomly distributed across trapping sites. Some of the differences may also be ascribed to the experimental protocol -- not all sites were sampled during the same time intervals: sites 1 through 5 were sampled during fall, early winter, late spring, and summer, while the remainder of the sites were sampled only during late spring and summer. Juvenile and subadult pocket mice begin appearing above ground from June through September. Depending on seed availability, subadults may be active for 40 to 70 days (O'Farrell et al. 1975), hence the letter-designated sites would be expected to show a higher proportion of subadults than the numbered sites.

The relationship observed between habitat type and mean body weight of occupants points to a significant caveat for all studies of the relationship of small mammals and their habitat. The relative abundance of a given species in a given habitat type is often considered a measure of the habitat's suitability for that species: habitats supporling more individuals are inferred to be of higher "quality" (see e.g., Schamberger and O'Neil 1986). Indeed, such a notion is becoming institutionalized as the basis for determining environmental impacts (USFWS 1980a and 1980b). As Van Horne (1983) observed, however, abundance may be a misleading indicator of habitat suitability. For example, cerlain habitats may serve as "dispersal sinks" (Lidicker 1975) into which individuals may immigrate and survive for a time, but not reproduce. Hence, for all intents and purposes, the existence of the habitat bears little upon individual fitness, yet population densities there may be paradoxically high. It is thus imperative that any analysis of "habitat suitability" account for the difference between productive and consumptive habitats. 



\section{COLD-BLOODED VERTEBRATE INVESTIGATIONS}

The primary objective of this task was to assess species composition and relative abundance of cold-blooded vertebrates in habitats similar to those likely to be affected by activities associated with the Basalt Waste Isolation Project. Another objective of this task was to provide estimates of natural variability in population parameters relevant to quantitative detection of project-induced change. This report incorporates data presented by Fitzner (1988).

\section{METHODS AND MATERIALS}

Five trapping sites were established in three habitat types during July 1986 . Three sites were in big sagebrush (Artemisia tridentata) habitat (sites 1,3,4, see Figure 1), one in spiny hopsage (Grayia spinosa) habitat (2), and one in bumed sagebrush habitat that is now dominated by cheatgrass (Bromus tectorum) and Russian thistle (Salsola kal) (5). Lizards and amphibians were captured in pitfall traps arranged in 5 by 5 grids with $10-\mathrm{m}$ spacing, with a single trap at each station. Piffall traps consisted of one-gallon cans buried flush with the ground surface and provided with wooden covers. Snakes were trapped using $61-\mathrm{m}$ drift fences each equipped with three $61-\times 91-\times 46-\mathrm{cm}$ funnel traps. These traps were constructed of 6-mm square mesh hardware cloth and $9.5-\mathrm{mm}$ plywood. No traps were baited.

In May 1987, seven additional trapping sites were established in seven habitat types (Figure 1). One site each was placed in big sagebrush (S), bitterbrush (Purshia tridentata) $(B)$, and rabbitbrush (Chrysothamnus spp.) ( $R$ ) dominated habitats. One site was placed in a sagebrushhopsage habitat associated with nearby talus (G); another was set in an area of compacted gravel with sparse vegetation (C). The sixth site was located in a bum-recovery area along a Russian thistle "drift" against a fence (T); the final site was located in a narrow riparian area along Rattlesnake Springs (RS). Fifty pitfall trapping stations were arranged at each site in single, double or triple rows with traps and rows spaced at least 10-m apart.

Trapping was conducted from July through October 1986 and between April and October 1987. Traps were opened on the first afternoon of each trapping session. Pitfall traps were checked daily, then closed on the final day of the trapping session (5 trap-nights/session in 1986, 4 trap-nights/session in 1987). Funnel traps were kept open for the duration of the trapping session. During mild weather funnel traps were checked two or three times per week. When temperatures rose to highs of about $90^{\circ} \mathrm{F}$, funnel traps were checked each morning or closed until temperatures moderated. 
Captured animals were transferred to a plastic bag for handling. Lizards and amphibians were marked with an individual combination of toe amputations. Snakes were individually marked by injecting tattooing ink under a unique combination of belly scales. All species were weighed using Pesola spring scales. The trap coordinate, species, sex, identification number, reproductive condition, total length, tail length, tail condition, and weight of trapped lizards and amphibians were recorded onto field forms, which were later placed into laboratory record books for storage. Data recorded for snakes included trap coordinate, identification number, species, total length, tail length, and weight. Statistics were calculated using Statview $512_{ \pm}$for the Macintosh@ (BrainPower 1986).

\section{BESULTS}

A total of 342 individuals were captured over a total of 13,549 trap-nights that were distributed unequally over the 12 trapping sites (Table 6). Because the focus of this study was on habitat affinities and species distributions, only qualitative analyses of species-habitat associations will be made. Six species of reptiles and one species of amphibian were captured (Table 7). Sideblotched lizards were by far the most frequently captured species, comprising $92.5 \%$ of all captures of lizards and $68 \%$ of all herpetile captures (Table 8 ). Snakes comprised $25 \%$ of all herpetiles captured. The predominant snakes captured were the yellow-bellied racer $(55.8 \%$ of snake captures) and the Great Basin gopher snake (40.7\%). Only two amphibians were captured. Both were Great Basin spadefoot toads captured at the Rattlesnake Springs trap site.

Species diversity was quite low (Shannon-Wiener $H=1.03$ ). Side-blotched lizards were found in all habitats save near the talus on Gable Mountain and on the gravel pad site. Wherever present, side-blotched lizards were the most common herpetile. The only other lizard species (northern sagebrush lizard and short-horned lizard) were obtained in bitterbrush habitat. No snakes were captured in rabbitbrush, tumbleweed, or on the gravel pad; however, sampling effort in these habitats was not focussed on snakes; i.e., no funnel traps were deployed in these areas.

Eighteen adult (8 males, 10 fernales) but no hatchling sagebrush lizards were captured at Bitterbrush Site. No sagebrush lizards were caught at any of the other trap sites. Sagebrush lizards were captured between April 20 and August 7. Length and weight data of captured sagebrush lizards are presented in Table 9.

Side-blotched lizards were captured between April 23 and October 10. Males comprised $50.5 \%$ of the 216 lizards for which sex was determined. Both sexes were equally represented in hatchlings but adult males were slightly more common than adult females. Length and weight 
IABLE6. Trapping Effort and Capture Rates of Cold-Blooded Vertebrates Across Trapping Sites

\begin{tabular}{|c|c|c|c|c|c|}
\hline \multirow[b]{2}{*}{ Habital } & \multirow[b]{2}{*}{ Site } & \multicolumn{2}{|c|}{ Trap - Niahts } & \multicolumn{2}{|c|}{ Capture rate $/ 100$ trap nights } \\
\hline & & Pitfall & Eunnel & Lizards & Snakes \\
\hline Sagebrush & $\begin{array}{r}1 \\
3 \\
4 \\
S \\
\text { otal }\end{array}$ & $\begin{array}{r}1325 \\
1325 \\
1325 \\
400 \\
4375\end{array}$ & $\begin{array}{r}669 \\
669 \\
609 \\
69 \\
2016\end{array}$ & $\begin{array}{l}7.17 \\
0.75 \\
1.81 \\
8.00 \\
3.68\end{array}$ & $\begin{array}{l}3.29 \\
2.84 \\
4.11 \\
1.45 \\
3.32\end{array}$ \\
\hline Hopsage & 2 & 1350 & 609 & 0 & 1.31 \\
\hline $\begin{array}{l}\text { Cheatgrass, Russian } \\
\text { thistle }\end{array}$ & 5 & 1300 & 609 & 2.00 & 0.99 \\
\hline Bitterbrush & B & 600 & 12 & 4.83 & 0 \\
\hline Rabbitbrush & $\mathbf{R}$ & 600 & .. & 4.83 & 0 \\
\hline Russian thistle & $T$ & 600 & -. & 0.50 & 0 \\
\hline Riparian & RS & 600 & .. & 0.83 & 0 \\
\hline Mixed shrub, talus & $\mathbf{G}$ & 400 & 69 & 0 & 2.90 \\
\hline $\begin{array}{l}\text { Cheatgrass, prickly } \\
\text { lettuce, gravel pad }\end{array}$ & C & 400 & -- & 0 & 0 \\
\hline
\end{tabular}

IABLE 7. Common and Scientific Names of Herpetiles Trapped in the Present Study

Common name
Western yellow-bellied racer
Northern Pacific rattlesnake
Great Basin gopher snake
Northem sagebrush lizard
Short-horned lizard
Side-blotched lizard
Great Basin spadefoot toad

\begin{tabular}{l}
\multicolumn{1}{c}{ Scientific name } \\
\hline Coluber constrictor \\
Crotalus vinidis \\
Pituophis melanoleucus \\
Sceloporus graciosus \\
Phrynosoma douglasii \\
Uta stansburiana \\
Scaphiopus intermontanus
\end{tabular}

data for adults are presented in Table 9. In 1986, hatchling side-blotched lizards (0.2-0.3 grams) were first captured on July 30 and as late as August 27. In 1987, hatchlings were first encountered on July 15 through August 28. 
IABLE 8. Number of Individual Herpetiles Captured in Each Habitat Sampled

\begin{tabular}{lrrrrrrrrrrrrr}
\multicolumn{110}{c}{} & \multicolumn{11}{c}{ Species } & 1 & $\mathbf{2}$ & $\mathbf{3}$ & $\mathbf{4}$ & $\mathbf{5}$ & $\mathbf{B}$ & $\mathrm{B}$ & $\mathrm{I}$ & $\mathrm{RS}$ & $\mathbf{G}$ & $\mathbf{S}$ & $\mathbf{C}$ & Tolal \\
Phrynosoma & 0 & 0 & 0 & 0 & 0 & 1 & 0 & 0 & 0 & 0 & 0 & 0 & 1 \\
Sceloporus & 0 & 0 & 0 & 0 & 0 & 18 & 0 & 0 & 0 & 0 & 0 & 0 & 18 \\
Uta & 95 & 0 & 10 & 24 & 26 & 10 & 29 & 3 & 5 & 0 & 32 & 0 & 234 \\
Coluber & 11 & 4 & 12 & 18 & 0 & 2 & 0 & 0 & 0 & 0 & 1 & 0 & 48 \\
Pituophis & 11 & 4 & 7 & 7 & 5 & 0 & 0 & 0 & 1 & 0 & 0 & 0 & 35 \\
Crotalus & 0 & 0 & 0 & 0 & 1 & 0 & 0 & 0 & 0 & 2 & 0 & 0 & 3 \\
Scaphiopus & 0 & 0 & 0 & 0 & 0 & 0 & 0 & 0 & 3 & 0 & 0 & 0 & 3 \\
Totals & 117 & 8 & 29 & 49 & 32 & 31 & 29 & 3 & 9 & 2 & 33 & 0 & 342
\end{tabular}

IABLE_.9. Morphology of Adult Lizards

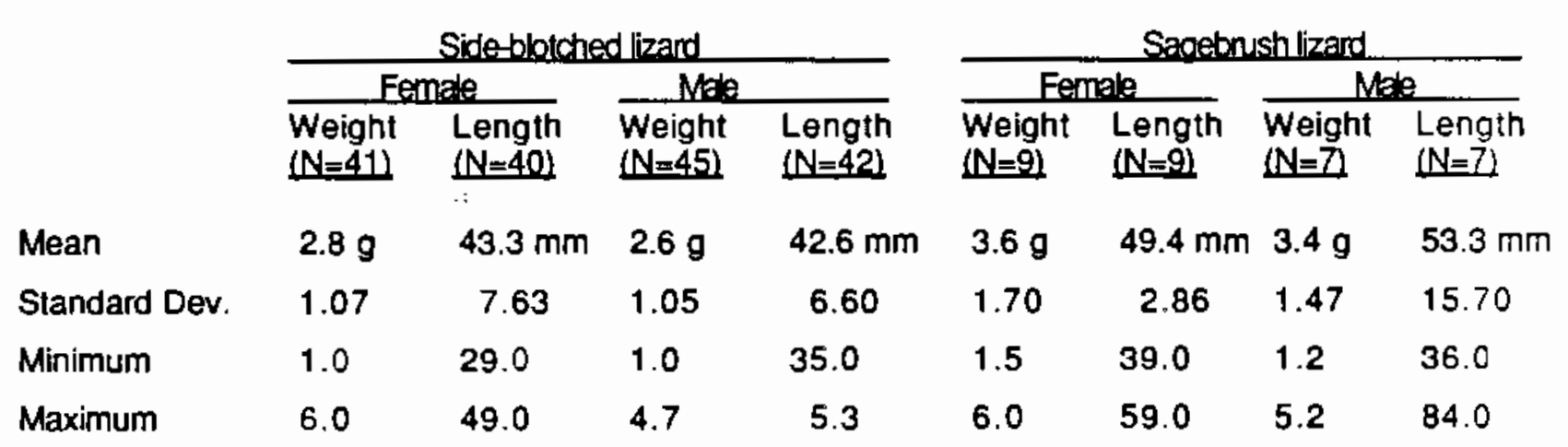

In 1986, the first snake captured was a gopher snake trapped on July 29 . The first yellowbellied racer was captured on August 20,1986. Latest 1986 captures for gopher snakes and yellow-bellied racers were October 10 and October 9 respectively. Snake trapping commenced on April 20 in 1987. First captures occurred on April 27 (gopher snake), April 23 (yellow-bellied racer), and May 1 (rattlesnake). Last 1987 captures were July 28 (gopher snake), August 19 (yellow-bellied racer) and September 25 (rattlesnake). 


\section{DISCUSSION}

All the species of amphibians and reptiles captured can be considered terrestrial. Although spadefoot toads reproduce in the water, the bulk of their lifetime is spent on land (Stebbins 1954). Spadefoot toads inhabit arid open areas in the interior of the Northwest (Nussbaum, Brodie, and Storm 1983). Our captures were adjacent to perennial water at Rattlesnake Springs where a few toads may be able to reproduce in spite of dry conditions. Our captures were made from the first week of May to the last week of June, corresponding with the breeding period described by Nussbaum, Brodie, and Storm (1983).

We caught northern sagebrush lizards only at the bitterbrush site. Stebbins (1985) notes that sagebrush lizards are found in areas of good light, open ground, and scattered low bushes, features present in the sagebrush sites as weil as the bitterbrush site. Our capture dates (20 April7 August) fit within the active period reported by Nussbaum, Brodie, and Storm (1983). No hatchyear sagebrush lizards were captured; however, our trapping efforts in the bitterbrush habitat ended before the usual hatch date for sagebrush lizard eggs (Stebbins 1954; Nussbaum, Brodie, and Storm 1983).

Published accounts indicate that side-blotched lizards occur in a wide variety of habitats and are the most abundant lizard in many parts of their range (Stebbins 1954; Nussbaum, Brodie, and Storm 1983). They were the most abundant lizard in all areas we trapped. Although no sideblotched lizards were captured on the Gable Mountain or the gravel pad sites, relatively little trapping effort was expended in these areas. Side-blotched lizards were active by late April and remained so until about mid-October. Nussbaum, Brodie, and Storm (1983) report an active period in the Pacific Northwest extending from late March to early November.

Gopher snakes, yellow-bellied racers, and rattlesnakes are common snakes in a wide variety of habitats in the Pacific Northwest. They are active from April or May until October. Gopher snakes and racers lay eggs in late June or early July and young emerge in mid to late August (racers) or late September to early October (gopher snakes). Rattlesnakes bear live young from mid September through October (Nussbaum, Brodie, and Storm 1983). Our capture dates for snakes generally coincided with published activity dates (Stebbins 1954, 1985; Fitch 1970; Nussbaum, Brodie, and Storm 1983). 


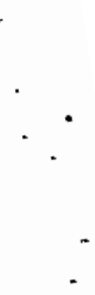




\section{ACKNOWLEDGEMENTS}

We acknowledge the following persons for their assistance with the collection, cataloging, and analysis of data: J. P. Bramson, R. Cuello, D. D. Dauble, L. E. Eberhardt, D. C. Girvin, J. A. Harbor, S. M. McCorquodale, J. P. McDonald, T. M. Poston, B. N. Potter, M. F.Radke, W. H. Rickard, C. K. Russel, T. D. Segna, and A. L. Styris. D. D. Dauble, L. E. Eberhardt, W. H. Rickard, and J. B. States provided valuable comments on drafts of this report. 



\section{REFERENCES}

BrainPower. 1986. Statview 512t. BrainPower, Incorporated, Calabasas, California.

Fitch, H. S. 1970. "Reproductive Cycles of Lizards and Snakes." Univ, Kansas Mus. Nat. Hist. Misc. Pub. No. 52. University of Kansas Press, Lawrence, Kansas.

Fitzner, R. E. 1988. Cold-Blooded Vertebrates at the Proposed Reference Repository Location in Southeastern Washington. PNL-6440, Pacific Northwest Laboratory, Richland, Washington.

Fitzner, R. E., W. H. Rickard, L. L. Cadwell, and L. E. Rogers. 1980. Raptors of the Hanford Site and Nearby Areas of Southcentral Washinaton. PNL-3212, Pacific Northwest Laboratory, Richland, Washington.

Gano, K. A. 1979. Analysis of SmalL MammalPopulations Inhabiting the Environs of a Low-Level Radioactive Waste Pond. PNL-2479, Pacific Northwest Laboratory, Richland, Washington.

Gano, K. A., and W. H. Rickard. 1982. "Small Mammals of a Bittertrush-Cheatgrass Community." Northwest Sci. 56:1-7.

Gano, K. A., et al. 1983. Ine Effects of Habitat on Recanture Probabilities of Small Mammals. PNL-10595, Pacific Northwest Laboratory, Richland, Washington.

Hedlund, J. D., and L. E. Rogers. 1976. Characterization of Small Mammal Populations Inhabiting the B-C Crib Environs. BNWL-2181, Pacific Northwest Laboratory, Richland, Washington.

Lidicker, W. Z., Jr. 1975. "The Role of Dispersal in the Demography of Small Mammals." In Small Mammals: Their Productivity and Population Dynamics, eds. K. Petrusewicz, E. B. Golley, and L. Ryszkowski, pp. 103-128. Cambridge University Press, Cambridge, England.

Nussbaum, R. A., E. D. Brodie, Jr., and R. M. Storm. 1983. Amphibians and Beptiles of the Pacific Northwest. University ldaho Press, Moscow, Idaho.

O'Farrell, T. P. 1975. "Small Mammals, Their Parasites and Pathologic Lesions on the Arid Lands Ecology Reserve, Benton County, Washington." Am.Mid. Nat. 93:377-387.

O'Farrell, T. P., et al. 1975. "A Population of Great Basin Pocket Mice, Perognathus parvus, in the Shrub-Steppe of South-Central Washington." Ecol. Monoar. 45:1-28.

Rickard, W. H., J. D. Hedlund, and R. G. Schreckhise. 1974. Mammals of the Hanford Beservation in Relation to Management of Radioactive Waste. BNWL-1877, Pacific Northwest Laboratory, Richland, Washington.

Schamberger, M. L., and L. J. O'Neil. 1986. "Concepts and Constraints of Habitat-Model Testing." In Wildlife 2000, eds.J. Verner, M. L. Morrison, and C. J. Ralph, pp. 5-10. The University of Wisconsin Press, Madison, Wisconsin.

Stebbins, R. C. 1954. Amphibians and Reptiles of Western North America. McGraw-Hill, New York, New York.

Stebbins, R. C. 1985. A Field Guide to Western Reptiles and Amphibians. Second Ed. Houghton Mifflin. Boston, Massachusetts. 
U. S. Fish and Wildlife Service (USFWS). 1980a. Habitat as a Basis for Environmental Assessment. Ecological Services Manual 101, U.S. Fish and Wildlife Service, Washington, D.C.

U. S. Fish and Wildlife Service (USFWS). 1980b Habitat Eyaluation Procedures (HEP). Ecological Services Manual 102, U.S. Fish and Wildife Service, Washington, D.C.

U.S. Nuclear Regulatory Commission (NRC). 1976. Preparation of Environmental Reperts for Nuclear Power Stations. Regulatory Guide 4.2, USNRC, Washington, D.C.

Van Horne, B. 1983. "Density as a Misleading Indicator of Habitat Quality." L.Wild. Manage. 47:893-901. 


\section{DISTRIBUTION}

No. of

Copies

OFFSITE

2 DOE/Office of Scientific and Technical Information

\section{ONSITE}

10 DOE Richland Operations
J. H. Anttonen
R. D. Freeberg
J. E. Mecca (7)
J. J. Sutey

44 Pacific NorthwestLaboratory
A. K. Baldwin (3)
P. A. Beedlow
C. A. Brandt
L. L. Cadwell
S. R. Coleman
D. H. Denham
D. D. Dauble
D. W. Dragnich
L. E. Eberhardt
P. A. Eddy
D. H. Fickeisen
R. E. Fitzner
M. J. Graham
R. H. Gray
J. M. Hales
P. C. Hays
S. E. King
E. B. Ljebow
S. M. McCorquodale
N. V. Mart
R. L. Newell
T. L. Page (10)
L. D. Poole
W. H. Rickard, Jr.
C. A. Schuler
J. B. States
J. A. Stottlemyre
J. W. Thielman
R. E. Wildung
Publishing Coordination (2)
Technical Report Files (2) 


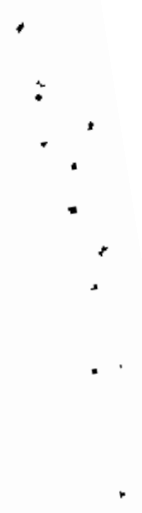

